\title{
Relationship between hepatic morphology and clinical and biochemical findings in morbidly obese patients
}

\author{
J. L. MANES, H. B. TAYLOR, AND G. B. STARKLOFF
}

From the Departments of Pathology and Surgery, St Louis University Medical Center, St. Louis, Missour

SYNOPSIS This study was undertaken to determine the interrelations between clinico-biochemical ${ }^{\sim} \Omega$ parameters and hepatic morphology in markedly obese patients. One hundred and sixty-six women $\vec{\circ}$ and 52 men comprise this series. There was a statistically significant association of carbohydrate $\forall$ metabolism disturbance with increasing age and corpulence and, in women, with hyperuricaemia $\sigma$ and morphological alterations of the liver. Menstrual irregularities also correlated well with hepatic morphology. The livers frequently exhibited steatosis, but other morphological changes were mild. $\vec{O}$ Compared with women, men had higher triglyceride values, more severe hepatic involvement, and poorer correlation of carbohydrate disturbances with hepatic histology. The results indicate a $\frac{0}{0}$ central role of the impaired carbohydrate utilization in the biochemical and hepatic alterations of ${ }^{\mathbb{D}}$ obesity.

Few studies in the severely obese correlating clinical and biochemical data with morphology of the liver are available. The early reports of Zelman (1952) and Westwater and Fainer (1958) were based on small series with limited laboratory data and all but one of the patients were males. The introduction of small bowel bypass to achieve weight reduction stimulated considerable controversy about the effects of these surgical procedures on the liver (Payne and DeWind, 1969; Drenick, Simmons, and Murphy, 1970; Juhl, Christoffersen, Baden, and Quaade, 1971; Salmon, 1971; Shibita, Mackenzie, and Huang, 1971; Meyerowitz, 1972). However, the influence of diverse factors (age, sex, corpulence, metabolic alterations) on hepatic morphology is nut well known. In this paper, we study the interrelations among several biochemical parameters, and we seek possible links between biochemical and clinical information with hepatic morphology.

\section{Materials and Methods}

The subjects studied were hyperphagic individuals undergoing jejunoileal bypass. The criteria for selection included obesity mainly due to hyperphagia, a minimum of $50 \mathrm{~kg}$ overweight, and a good surgical risk. Clinical data were obtain through questioning by one of the authors in more than half of the patients and from medical records or mailed questionnaires in the remainder. Except $\stackrel{\odot}{\stackrel{\circ}{\varrho}}$ for diabetes and obesity, no patient had conditions $\overrightarrow{\vec{P}}$ known to alter hepatic histology (active gastrointest- $\frac{9}{3}$ inal disease, anaemia, history of alcoholism, hepatitis, or drug addiction). Few patients were taking medicines. Seventeen women taking oral contraceptives were included because after analysis? of the data their inclusion did not significantly affect the results.

The corpulence was expressed as percentage obesity which was calculated by dividing patient's weight by medium frame ideal weight of the Metro- $\frac{\text { S }}{3}$ politan Life Insurance Company as given by Geigy $\frac{D}{O}$ (1962); 0 represents the ideal and 100 is double the desired weight.

Fasting serum calcium, phosphorus, cholesterol, uric acid, blood urea nitrogen, total protein, total N bilirubin, alkaline phosphatase, lactic acid dehydro- $\mathrm{W}$ genase, and glutamic oxalacetic transaminase $\bar{\sigma}$ (GOT) were done in all patients on the Technicon 6 SMA $12 / 60^{1}$. The three-hour glucose tolerance test (OGTT) was carried out following the recommend- $\stackrel{\oplus}{?}$ ations of the University Diabetes Program and the American Diabetes Association Committee on 
Statistics (1969). The plasma glucose was determined by the alkaline ferricyanide method in the AutoAnalyzer. In the bromsulphalein (BSP) retention test, $5 \mathrm{mg}$ of dye per $\mathrm{kg}$ of body weight was injected in patients weighing $100 \mathrm{~kg}$ or less. Heavier subjects received $500 \mathrm{mg}$. Retention of the dye was measured by spectrophotometry. Fasting triglycerides (Tg) were determined enzymatically using a commercially available $\mathrm{kit}^{2}$. The method of Noble (1969) was used for the electrophoretic separation of plasma lipoproteins in agarose gel. The prothrombin time (PT) was estimated by the method of Biggs and Macfarlane as modified by Gaston, Brooks, Blumenthal, and Miller (1971). Serum folates were assayed by a microbiological technique employing Lactobacillus casei.

The upper limits of normal in this laboratory, established from healthy blood donors, are: cholesterol, $260 \mathrm{mg} / 100 \mathrm{ml}$; uric acid, $8.3 \mathrm{mg} / 100 \mathrm{ml}$ in men and $7.7 \mathrm{mg} / 100 \mathrm{ml}$ for females; GOT, $50 \mathrm{~m} \mathrm{U} /$ $\mathrm{ml}$. The lower limits of normal for serum folates is $6 \mathrm{ng} / \mathrm{ml}$. We consider an OGTT result 'normal' when plasma glucose at one hour is less than 175 $\mathrm{mg} / 100 \mathrm{ml}$ and at two hours less than $130 \mathrm{mg} / 100 \mathrm{ml}$; 'diabetic' if the sum of the fasting, one-, two-, and three-hour values (in $\mathrm{mg} / 100 \mathrm{ml}$ ) is 600 or more (University Group Diabetes criteria); and 'abnormal' when the values fall between 'normal' and 'diabetic'.

Wedge biopsies of the liver were taken at the beginning of the bypass operation by one of us (G.B.S.). Sections were routinely stained with haematoxylin and eosin (H\&E) and occasionally by other techniques (Oil red 0 for lipids; PAS stains for reticulin and collagen fibres and for iron). Hepatic histology was assessed without knowledge of laboratory data; two of us (J.L.M. and H.B.T.) agreed on the histological interpretation. Fatty change was graded minimal $(<5 \%$ of hepatocytes had visible fatty droplets), mild (5-25\%), moderate $(25-50 \%)$, and marked $(>50 \%)$. We recorded nuclear vacuolization only if it affected more than $5 \%$ of parenchymal cell nuclei. Other histological findings (fibrosis, inflammation, pigments, lipogranulomas) were graded mild, moderate, and marked.

${ }^{2}$ Calbiochem, San Diego, Calif. 92112.
Results

\section{CLINICAL FINDINGS}

The distribution by age and sex is shown in table $I$. The mean age of the females was 35.7 and that of the males 34.9 years. The heaviest subject weighed $241 \mathrm{~kg}$ and the lightest $\mathbf{9 4 . 2} \mathrm{kg}$. In males, the mean percentage overweight was $117 \cdot 3 \pm 36 \cdot 1$; in females it was $134 \pm 36 \cdot 9$. Table II shows the corpulence. Thirteen patients were Negro and the remainder were Caucasian. Cholelithiasis, past or present, was noted in $72(33 \%)$ subjects. In 59 women with this information available (all under 37 years of age) 32 either had abnormal menstrual periods or complained of sterility. Two diabetic patierts were taking insulin and four others were on oral antidiabetic medication. Clinical gout was present in five males and two females. About a fourth of the individuals gave a history of transient hypertension but very few were receiving antihypertensive medication. Less than $10 \%$ of the patients had minor ECG changes and/or a history of anginà pectoris. (Exertional dyspnoea, encountered fairly often, was usually attributed to overweight.)

\begin{tabular}{llr}
\hline Age & Males & Females \\
\hline $16-29$ & $14(27 \cdot 0 \%)$ & $46(27 \cdot 7 \%)$ \\
$30-39$ & $21(40.4 \%)$ & $63(38.0 \%)$ \\
$40-60$ & $17(32.6 \%)$ & $57(34 \cdot 3 \%)$ \\
Total & $52(100.0 \%)$ & $166(100.0 \%)$ \\
\hline
\end{tabular}

Table I Distribution by sex and age

\begin{tabular}{lll}
\hline $\begin{array}{l}\text { Percentage } \\
\text { Overweight }\end{array}$ & Males & Females \\
\hline$<120$ & $29(55 \cdot 8 \%)$ & $65(39 \cdot 2 \%)$ \\
$120-149$ & $13(25 \cdot 0 \%)$ & $51(30 \cdot 7 \%)$ \\
$150 \&$ over & $10(19 \cdot 2 \%)$ & $50(30 \cdot 1 \%)$ \\
\hline
\end{tabular}

Table II Corpulence

\section{LABORATORY DATA}

The fasting and one-, two-, and three-hour values in the OGTT are given in table III. Table IV shows the relationship of OGTT with uric acid and $\mathrm{Tg}$ in women. In men there was no obvious association among these three parameters. Table $\mathrm{V}$ shows the

\begin{tabular}{|c|c|c|c|c|c|c|c|c|c|c|}
\hline \multirow[t]{2}{*}{$O G T T$} & \multicolumn{5}{|c|}{ Males } & \multicolumn{5}{|c|}{ Females } \\
\hline & No. & $\begin{array}{l}\text { Fasting } \\
\text { Mean SD }\end{array}$ & $\begin{array}{l}\text { One Hour } \\
\text { Mean SD }\end{array}$ & $\begin{array}{l}\text { Two Hour } \\
\text { Mean SD }\end{array}$ & $\begin{array}{l}\text { Three Hour } \\
\text { Mean SD }\end{array}$ & No. & $\begin{array}{l}\text { Fasting } \\
\text { Mean SD }\end{array}$ & $\begin{array}{l}\text { One Hour } \\
\text { Mean SD }\end{array}$ & $\begin{array}{l}\text { Two Hour } \\
\text { Mean SD }\end{array}$ & $\begin{array}{l}\text { Three Hour } \\
\text { Mean SD }\end{array}$ \\
\hline $\begin{array}{l}\text { Normal } \\
\text { Abnormal } \\
\text { Diabetic }\end{array}$ & $\begin{array}{l}10 \\
21 \\
15\end{array}$ & $\begin{array}{r}92 \pm 10 \\
98 \pm 10 \\
148 \pm 62\end{array}$ & $\begin{array}{l}143 \pm 15 \\
188 \pm 26 \\
261 \pm 89\end{array}$ & $\begin{array}{l}102 \pm 18 \\
134 \pm 29 \\
260 \pm 110\end{array}$ & $\begin{array}{r}78 \pm 18 \\
82 \pm 18 \\
173 \pm 104\end{array}$ & $\begin{array}{l}43 \\
60 \\
38\end{array}$ & $\begin{array}{r}90 \pm 9 \\
100 \pm 10 \\
152 \pm 55\end{array}$ & $\begin{array}{l}137 \pm 19 \\
190 \pm 33 \\
284 \pm 78\end{array}$ & $\begin{array}{l}106 \pm 18 \\
149 \pm 25 \\
258 \pm 95\end{array}$ & $\begin{array}{r}80 \pm 19 \\
91 \pm 21 \\
178 \pm 73\end{array}$ \\
\hline
\end{tabular}

Table III Results of oral glucose tolerance test (OGTT) 


\begin{tabular}{|c|c|c|c|c|}
\hline & \multicolumn{2}{|c|}{ Uric Acid } & \multicolumn{2}{|l|}{$T g^{1}$} \\
\hline & Normal & High & Normal & High \\
\hline $\begin{array}{l}\text { Normal } \\
\text { Abnormal } \\
\text { Diabetic } \\
\text { Significance }^{2}\end{array}$ & $\begin{array}{l}39 \\
48 \\
24\end{array}$ & $\begin{array}{r}4 \\
12 \\
14\end{array}$ & $\begin{array}{l}26 \\
28 \\
16\end{array}$ & $\begin{array}{l}11 \\
20 \\
18\end{array}$ \\
\hline
\end{tabular}

Table IV Relationship of OGTT to uric acid and Tg (women only)

${ }^{1}$ Upper limits of normal are those given by Frederickson et al (1967)

${ }^{2}$ All analysis of data for significant differences in this study was by the $\chi^{2}$ test of contingency tables.

\begin{tabular}{|c|c|c|c|c|c|c|}
\hline \multirow[t]{2}{*}{ OGTT } & \multicolumn{3}{|c|}{ Age Group } & \multicolumn{3}{|c|}{ Percentage Overweight } \\
\hline & $16-29$ & $30-39$ & $40-60$ & $<120$ & $120-149$ & 150 \& Over \\
\hline $\begin{array}{l}\text { Normal } \\
\text { Abnormal } \\
\text { Diabetic } \\
\text { Significance }\end{array}$ & $\begin{array}{r}24 \\
17 \\
7\end{array}$ & $\begin{array}{c}15 \\
35 \\
25 \\
\mathrm{P}<0.005\end{array}$ & $\begin{array}{l}14 \\
29 \\
21\end{array}$ & $\begin{array}{l}27 \\
38 \\
15\end{array}$ & $\begin{array}{l}20 \\
22 \\
10 \\
<0.001\end{array}$ & $\begin{array}{r}6 \\
21 \\
28\end{array}$ \\
\hline
\end{tabular}

Table V Relationship of OGTT to age and corpulence (all patients)

\begin{tabular}{|c|c|c|c|c|}
\hline \multirow[t]{2}{*}{ Age Group } & \multicolumn{2}{|l|}{ Males } & \multicolumn{2}{|l|}{ Females } \\
\hline & No. of Cases & $T g(m g \%)$ Mean $S D$ & No. of Cases & $T g(m g \%)$ Mean $S D$ \\
\hline $\begin{array}{l}16-29 \\
30-39 \\
40-49 \\
50-60\end{array}$ & $\begin{array}{c}12 \\
20 \\
13 \\
2\end{array}$ & $\begin{array}{c}205 \pm 73 \\
231 \pm 92 \\
274 \pm 180 \\
67 \pm 0.6\end{array}$ & $\begin{array}{l}33 \\
54 \\
36 \\
10\end{array}$ & $\begin{array}{l}141 \pm 58 \\
170 \pm 87 \\
176 \pm 87 \\
123 \pm 57\end{array}$ \\
\hline
\end{tabular}

Table VI Triglycerides $(T g)$ by age and sex

relationship of OGTT with age and corpulence. As tables IV and V indicate, there was a statistically significant association between the degree of abnormality of the OGTT and corpulence and age in both sexes and with uric acid in females; the link Tg-OGTT did not reach statistical significance (table IV).

The Tg results are shown in table VI. Note the higher values in men than in women. Secondly, the peak levels are in the $30-50$ age group in both sexes. Contraceptive hormones may have affected Tg (Stokes and Wynn, 1971), but numbers were too small and scattered in subgroups to draw conclusions or to affect the overall results.

In 21 patients $(9.6 \%)$ the serum cholesterol was between 261 and $300 \mathrm{mg} / 100 \mathrm{ml}$ and in 11 patients $(5 \%)$ it was over $300 \mathrm{mg} / 100 \mathrm{ml}$. No relationship was evident between hypercholesterolaemia and other factors, except possibly age.

Lipoprotein electrophoresis usually revealed normal or type IV patterns (of Fredrickson, Levy, and Lees, 1967). As expected, the type IV patterns occurred in subjects with highest $\mathrm{Tg}$ levels.

A single determination revealed hyperuricaemia in $20(38.4 \%)$ men and in $35(20.7 \%)$ women, which is a significant sex difference $(P<0.025)$. After ${ }^{\circ}$ taking into account the abnormalities of carbo- $\Rightarrow$ hydrate metabolism, no association was found $\frac{\mathrm{O}}{3}$ between uricaemia and corpulence, age, or $\mathrm{Tg}$ (or $\vec{T}$ among the last three parameters).

The BSP retention test was done on 111 occasions; 50 patients retained between 7 and $20 \%$ of the dye at 45 minutes, 10 subjects had over $20 \%$ retention, and in 51 patients the results were normal.

Serum folates between 2 and $5.9 \mathrm{ng} / \mathrm{ml}$ occurred in $40(29.8 \%)$ of 134 patients who were not anaemic. No other abnormalities (clinical, metabolic, or음 histology of the liver) could be associated with low folates.

Protein electrophoresis, as well as tests to evaluaten endocrine (thyroid, adrenals) and haematological ${ }^{\circ}$ status, consistently gave normal results. The 0 alkaline phosphatase, PT, albumin, and total ${ }_{\omega}^{N}$ bilirubin were abnormal in less than $5 \%$ of the patients, therefore, they were not compared witho other functions.

HISTOLOGICAL FINDINGS OF THE LIVER The microscopic findings are summarized in table VII. 


\begin{tabular}{|c|c|c|c|c|c|c|c|c|c|}
\hline \multirow[t]{2}{*}{$\begin{array}{l}\text { Histological } \\
\text { Change }\end{array}$} & \multicolumn{3}{|c|}{ Steatosis } & \multirow[t]{2}{*}{$\begin{array}{l}\text { Lipogranu- } \\
\text { lomas }\end{array}$} & \multicolumn{2}{|c|}{$\begin{array}{l}\text { Lobular and Portal } \\
\text { Fibrosis }\end{array}$} & \multicolumn{2}{|c|}{ Inflammation } & \multirow[t]{2}{*}{$\begin{array}{l}\text { 'Ballooned' } \\
\text { Nuclei }(>5 \%)\end{array}$} \\
\hline & $<25 \%$ & $25-50 \%$ & $>50 \%$ & & Slight & Moderate & Portal & Lobular & \\
\hline $\begin{array}{l}\text { Males }(\%) \\
\text { Females }(\%)\end{array}$ & $\begin{array}{l}40 \cdot 0 \\
63 \cdot 2\end{array}$ & $\begin{array}{l}32 \cdot 7 \\
20 \cdot 0\end{array}$ & $\begin{array}{l}27 \cdot 3 \\
16 \cdot 8\end{array}$ & $\begin{array}{l}36 \cdot 4 \\
15 \cdot 0\end{array}$ & $\begin{array}{l}7 \cdot 6 \\
7 \cdot 2\end{array}$ & $\begin{array}{r}11 \cdot 5 \\
2 \cdot 4\end{array}$ & $\begin{array}{l}21 \cdot 1 \\
16 \cdot 8\end{array}$ & $\begin{array}{r}11 \cdot 7 \\
8 \cdot 4\end{array}$ & $\begin{array}{l}23 \cdot 2 \\
22 \cdot 9\end{array}$ \\
\hline
\end{tabular}

Table VII Histological findings in the liver

\section{Fatty change}

This was the most prominent abnormality. In over half of the instances, especially in mild and moderate steatosis, the fat was in the form of large droplets mostly in a central and midlobular position (fig 1). When fatty metamorphosis became severe, it was either diffuse or predominantly centrilobular. If some portal fibrosis supervened, fat was often located at the periphery of the lobules and some of it was trapped within the enlarged portal tracts (fig 2). Small and medium size fatty droplets tended to be diffusely distributed (fig 3 ).

\section{Lipogranulomas}

These are defined as groups of Kupffer cells, lipophages, and a mixed inflammatory infiltrate (lymphocytes with some eosinophils and neutrophils). A single, large vacuole of lipid surrounded by leucocytes is here considered a fatty cyst. Lipogranulomas were usually small and only two contained giant cells. Lipogranulomas were most abundant and conspicuous in centrilobular areas (fig 4). Livers containing lipogranulomas usually also exhibited steatosis (not always severe) with large globules of fat.

\section{Parenchymal inflammation}

Lymphocytic or neutrophilic infiltrates frequently occurred in clumps coexisting with fatty cysts and lipogranulomas. These changes were usually mild.

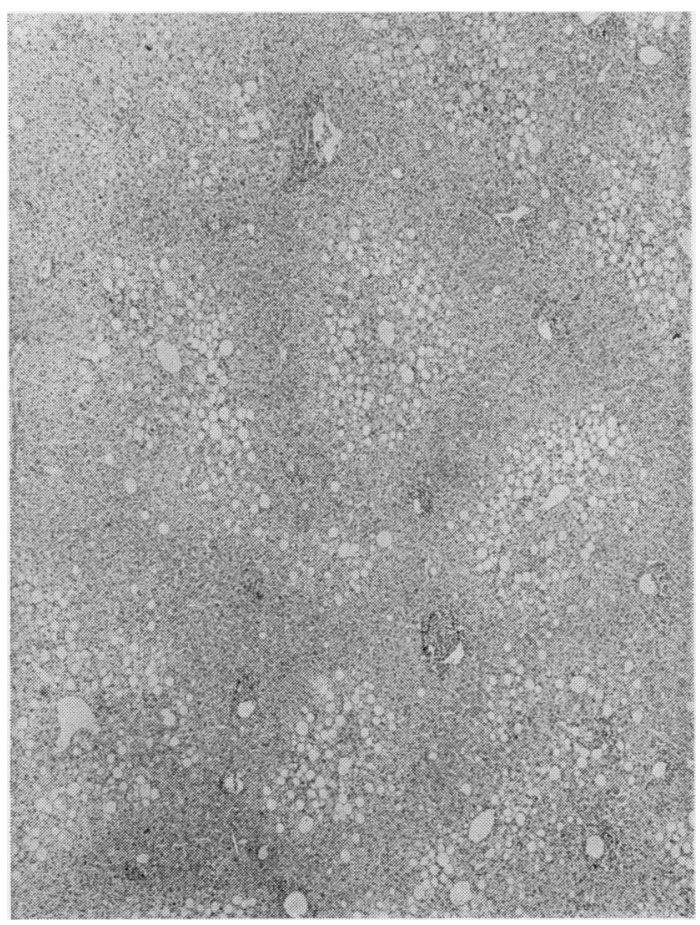

Fig 1 Moderate fatty change. Note the predominantly midlobular and centrilobular large lipid vacuoles. $H \& E, 40$

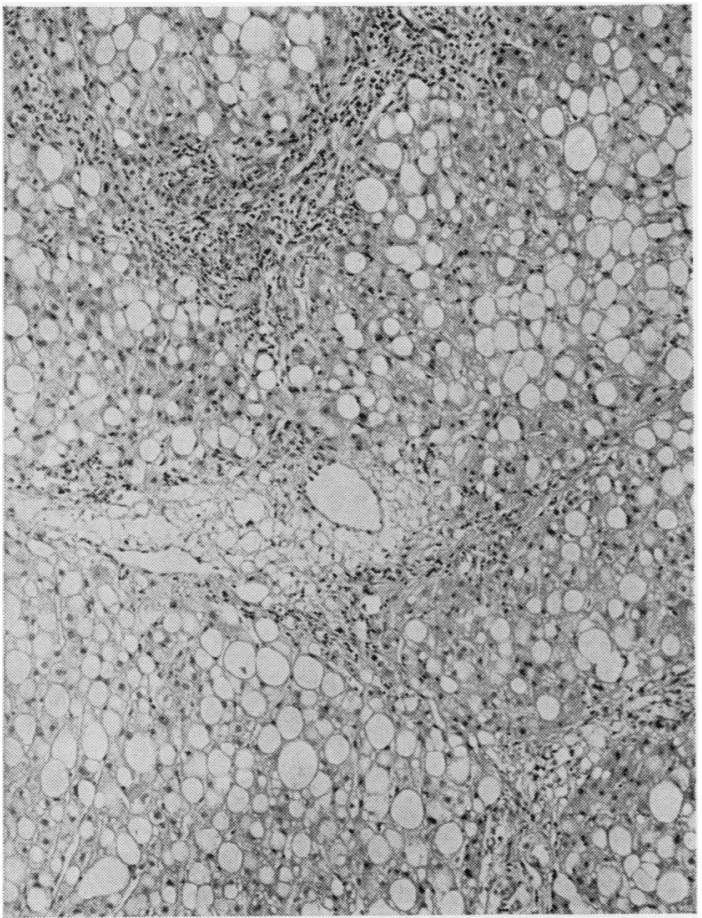

Fig 2 Marked fatty metamorphosis and fibrosis. Globules of fat have coalesced, ruptured, or have been engulfed in poorly demarcated portal triads. $H \& E, 100$ 


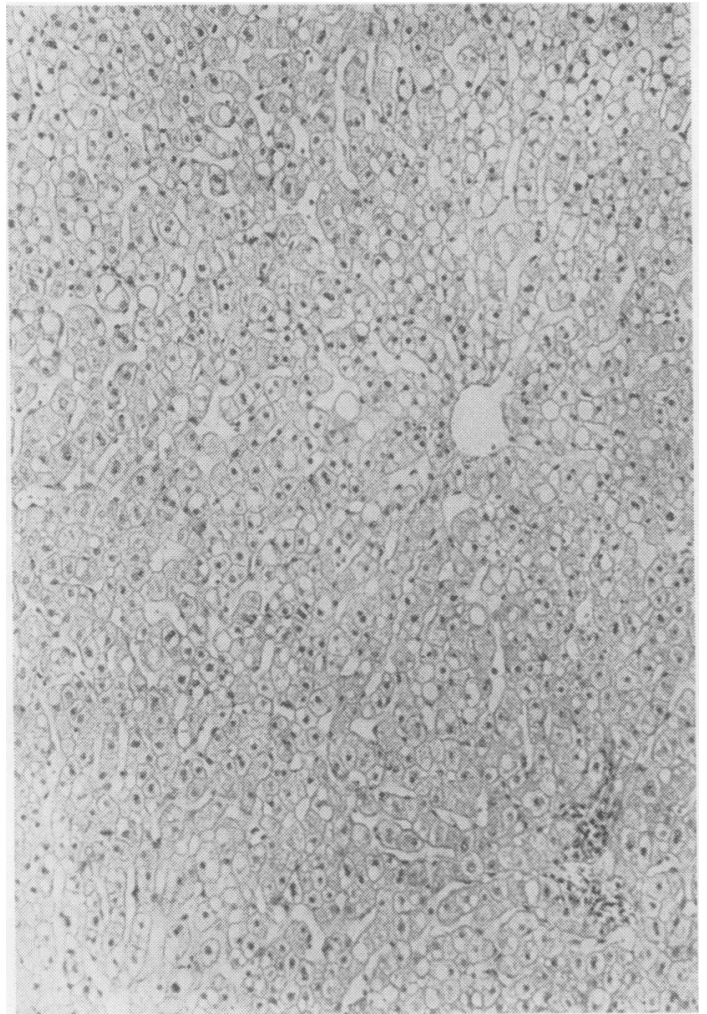

Fig 3

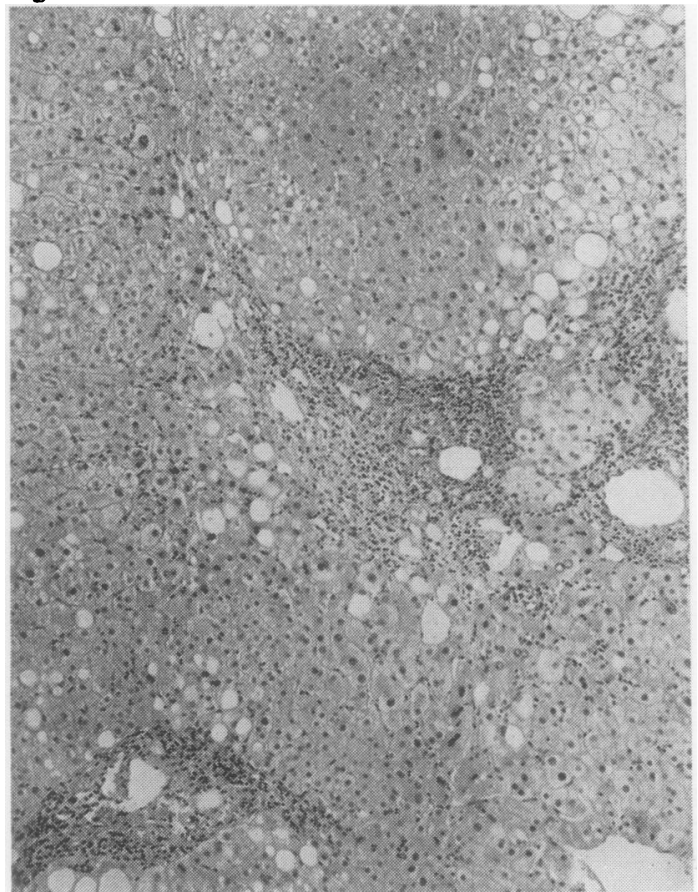

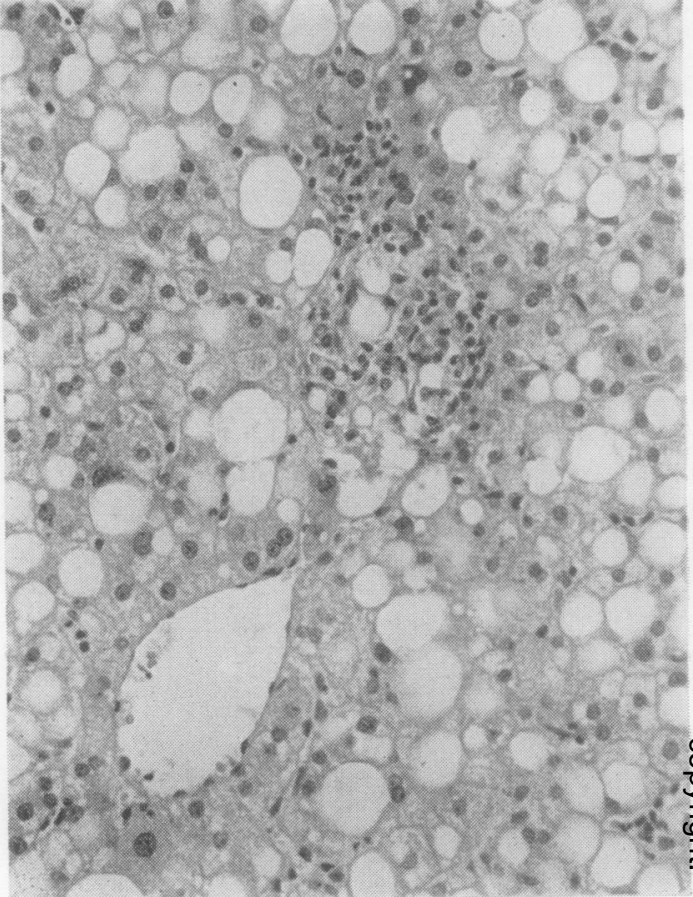

Fig 4

Fig 3 Diffuse distribution of small and medium size droplets of lipids. $H \& E, 150$

Fig 4 Lipogranuloma near a central vein. Fat vacuoles and mixed cellular component. $H \& E, 250$

Fig 5 Thin fibrous strands bridging mildly enlarged portal tracts. The steatosis is here mostly periportal. $H \& E, 100$ 
Fibrosis (portal and lobular)

A few, thin fibrous strands were often seen in the centre of the lobules. However, more severe involvement with portal and portal-central vein bridging were uncommon (fig 5). Fibrosis was associated, in decreasing order of frequency, with polymorphonuclear leucocytic infiltrates, lipogranulomas, and fatty change.

\section{Portal spaces}

Mononuclear, and less often neutrophilic, infiltrates were present to a variable degree. If only an isolated subcapsular portal tract appeared abnormal, it was not considered significant. Mild proliferation of bile ducts was seen in a few biopsies.

\section{Nuclear vacuolization}

In $\mathbf{H}$ and $\mathbf{E}$ preparations, 'empty'-appearing, completely 'ballooned' nuclei were seen in periportal areas, often with a patchy distribution (fig 6). Less commonly, small vacuoles were noticed within pleomorphic nuclei of hepatocytes; the location in the lobule of this type of nuclear inclusion was not constant.

\section{Pigments}

Ceroid (lipochrome) was normal or decreased. The few bile plugs and iron which were found occurred in the most abnormal livers.

\section{Other histological findings}

Proliferation of Kupffer cells and necrosis of hepatocytes were uncommon. As expected, the latter often coexisted with neutrophilic inflammation. No alcoholic hyaline (Mallory bodies) was identified in any biopsy.

\section{Correlation of Hepatic Morphology with Clinical and Biochemical Data}

In this series, in women, abnormal carbohydrate metabolism is the single most important finding associated with hepatic changes (table VIII). This link is stronger in females over $\mathbf{3 0}$ years old than

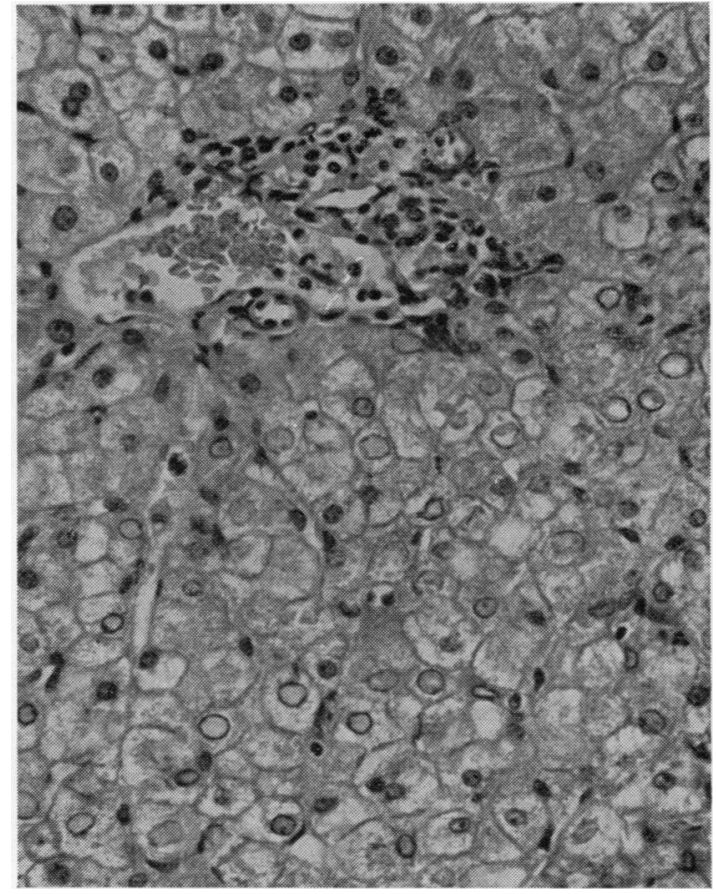

Fig 6 'Ballooned' type of nuclear vacuolization. Observe its patchy and periportal distribution. $H \& E, 250$

in younger women. Nuclear vacuolization ('ballooned' nuclei) is supposedly a common histological feature in livers of diabetics. We found it in $45 \%$ of the 'diabetic', in $18.3 \%$ of the 'abnormal', and in $14 \%$ of the 'normal' women. It was usually associated with fatty metamorphosis of the liver. Sixteen of 32 patients with menstrual irregularities had over $25 \%$ hepatic steatosis; by contrast only three of 27 normally menstruating women showed a similar degree of liver involvement. This difference was not explained by the degree of carbohydrate tolerance. After making allowance for the role of carbohydrate metabolism alteration and for gynaecological history, neither the clinical (corpulence, age)

\begin{tabular}{|c|c|c|c|c|}
\hline \multirow[t]{3}{*}{$O G T T$} & \multicolumn{4}{|c|}{ Hepatic Abnormalities } \\
\hline & \multicolumn{2}{|c|}{ Steatosis } & \multicolumn{2}{|c|}{ Fibrinosis } \\
\hline & $<25 \%$ & $25 \% \&$ Over & None & Present \\
\hline $\begin{array}{l}\text { Normal } \\
\text { Abnormal } \\
\text { Diabetic } \\
\text { Significance }\end{array}$ & $\begin{array}{l}37 \\
39 \\
10\end{array}$ & $\begin{array}{r}6 \\
21 \\
28\end{array}$ & $\begin{array}{l}42 \\
55 \\
30\end{array}$ & $\begin{array}{l}1 \\
5 \\
8\end{array}$ \\
\hline
\end{tabular}

Table VIII Correlation between OGTT and hepatic morphology (women only) $x^{2}$ test not calculated because one or more expected values is less than 5 . 
condition nor the metabolic (lipids, uric acid) parameter correlated well with hepatic morphology.

In men, histological changes of the liver were more severe (table VII) and could not statistically be linked to any clinical or metabolic dysfunction.

Thirty-seven patients had slightly elevated GOT, and of these, eight had no or mild pathological findings in the liver, 15 showed some hepatic fibrosis, 22 had marked fatty change, and 16 parenchymal or portal inflammation. Conversely, 15 out of 24 subjects with hepatic fibrosis and 22 of 40 with marked hepatic steatosis had elevations of the GOT. Mild or moderate hepatic steatosis was not associated with GOT elevations. Bromsulphalein was not reliable in predicting hepatic alterations in this study.

\section{Discussion}

The results of this study underscore the importance of carbohydrate metabolism in exogenous obesity. The majority of the patients had either an 'abnormal' or a 'diabetic' OGTT. Moreover, diabetes, when present, was mild in most patients. These facts are interpreted as evidence of the obesity-associated character of the carbohydrate disturbance. A key mediator, extensively studied in recent years, is insulin. Hyperinsulinism has been linked to corpulence, hyperglycaemia, and hypetriglyceridaemia (Rosselin, Claude, Eschwege, Patois, Warnet, and Richard, 1971). The relationship between insulin and adipose tissue has been extensively studied (Björntorp, Berchtold, Holm, and Larsson, 1971), and the hyperinsulinism of obesity has been thought as mainly due to the 'resistance' of the adipocyte to the action of insulin. Surprisingly little is known about the role that the liver may play in this hyperinsulinism. Abnormal glucose tolerance and high insulin levels also occur in cirrhosis, but it has been suggested that these are caused by shunting of insulin-containing portal blood (Conn, Schreiber, and Elkington, 1971; McCullough, Tzargournis, Greenberger, and Linscheer, 1971).

The other two frequently elevated values in this study were the $\mathrm{Tg}$ and uric acid. To interpret $\mathrm{Tg}$ levels, the influence of age (Schaefer, 1964) and probably sex should be taken into account; age-adjusted criteria are used to determine the upper limits of 'normal' (Fredrickson et al; 1967). However, there is little information on the possible influence of sex on $\mathrm{Tg}$ values. In our material, hypertriglyceridaemia was more closely associated with sex and age variation than with corpulence, abnormal carbohydrate metabolism, or hyperuricaemia. These findings tend to parallel those of other studies in normal, mildly obese and diabetic individuals (Allard and Goulet, 1968; Plauchu节 Pousset, Montgolfier, Guibert, and Kressmann, 1971)을

Inasmuch as the method used by us is not very: specific for uric acid, and furthermore, serum urate? levels fluctuate fairly widely even in the same subjec $\bar{T}$ (Goldstein, Becker, and Moore, 1972), the uric acide values should be interpreted with caution. Even recognizing such limitations, our data show highe $\mathbb{8}$ uric acid levels in men than in women.

The coexistence of high $\Gamma \mathrm{g}$, hyperglycaemia, and obesity is well known (Emmerson and Knowles; 1971; Mertz, 1972), although a precise link among these factors is difficult to establish. Except between uricaemia and hyperglycaemia (and only in females)? we were unable to find a statistically significanf association among these parameters.

Elevations of GOT, even slight, correlated welP with hepatic fibrosis and inflammation, and to क्र lesser extent with hepatic steatosis. Determinations of GOT have more practical value when there are no other conditions known to affect the GOT, as in our patients. In contrast to GOT, BSP was m poor test in predicting the severity of hepatico alterations. This may be explained by the difficulty in calculating an adequate dose and by the irregularo distribution of the dye in the obese.

Hepatic steatosis in obesity has long been ref ognized. In the first studies, carried out in males no relationship could be established between hepatic pathology and any biochemical data. Wề report here similar findings in men. However, if should be pointed out that the number of males in the present and in previous studies is relativelye small. To our knowledge, no comparison of biochemical and clinical information with histology of the liver has been previously attempted in markedly. obese females. In investigations on diabetic patients $\frac{\hat{O}}{2}$ mostly mildy obese females, the degree of hepatico fatty metamorphosis depended on the degree of overweight not on the severity of diabetes (Beringero and Thaler, 1970; Wasastjerna, Reissell, Karjalainen, and Ekelund, 1972). In our material impairment of carbohydrate metabolism seems more important than corpulence in producing hepatic changes. Perhaps ife. might be concluded that, at least in females, the coexistence of both obesity and 'diabetic' alteration? is much more likely to cause fatty liver than if only one factor is present.

Gout has been implicated as a cause of fattyo liver (Hennecke and Südhoff, 1970), but it remains unclear whether the uric acid alteration or the fre $\frac{\pi}{D}$ quently coexisting obesity and 'diabetes' are res sponsible for the hepatic steatosis. Our data are inconclusive in this respect, but carbohydrateo alterations seem to play a more important role than gout. Hypercholesterolaemia (Leevy, 1962), 零 
hypertriglyceridaemia, or high fatty acids, per se, are not known to be associated with liver damage. This is also evident in the present work.

We report here a close association between menstrual disturbances and hepatic abnormalities in young obese females. This, to our knowledge, has not been previously described, and further studies are needed.

Our data suggest both unpredictable and more severe liver involvement in obese men than in women. Review of other reports (Zelman, 1953; Westwater and Fainer, 1958; Meyerowitz, 1972) appears to support this view. The reason for this sex difference is not clear. Seemingly, the alterations which should coexist with obesity to cause hepatic abnormalities are less common or less severe in females.

Histologically, although fatty change in the liver was common, significant fibrosis was infrequent, and when the latter occurred, necrosis and inflammation often coexisted. Thus, the last two factors, rather than steatosis, are the important fibrogenetic stimuli in the liver. This concept is held by most investigators (Schaffner and Popper, 1970; Smetana, 1972) studying fatty livers of diverse aetiology. The role of lipogranulomas (Christoffersen, Braendstrup, Juhl, and Poulsen, 1971), if any, awaits further investigation (in our material it did not seem to be prominent). The pathway leading to cirrhosis in the obese-a relatively uncommon event-is probably similar to the one operating in other micronodular cirrhosis.

\section{References}

Allard, C., and Goulet, C. (1968). Serum lipids: an epidemiological study of an active Montreal population. Canad. med. Ass. J., 98, 627-637.

American Diabetes Association Committee on Statistics (1969). Standardization of the oral glucose tolerance test. Diabetes, 18, 299-310.

Beringer, A., and Thaler, H. (1970). The relationship between diabetes mellitus and fatty liver. Germ. med. Mth., 15, 615-618.

Björntorp, P., Berchtold, P., Holm, J., and Larsson, B. (1971). The glucose uptake of human adipose tissue in obesity. Europe. $J$. clin. Invest., 1, 480-485.

Christoffersen, P., Braendstrup, O., Juhl, E., and Poulsen, H. (1971). Lipogranulomas in human liver biopsies with fatty change: a morphological, biochemical and clinical investigation. Acta path. microbiol. scand., 79A, 150-158.

Conn, H. O., Schreiber, W., and Elkington, S. G. (1971). Cirrhosis and diabetes. II. Association of impaired glucose tolerance with portal-systemic shunting in Laennec's cirrhosis. Amer. J. dig. Dis., 16, 227-239.

Drenick, E. J., Simmons, F., and Murphy, J. F. (1970). Effect on hepatic morphology of treatment of obesity by fasting, reducing diets and small-bowel bypass. New Engl. J. Med., 282, 829-834.

Emmerson, B. T., and Knowles, B. R. (1971). Triglyceride concentrations in primary gout and gout of chronic lead nephropathy. Metabolism, 20, 721-729.

Fredrickson, D. S., Levy, R. I., and Lees, R. S. (1967). Fat transport in lipoproteins; an integrated approach to mechanisms and disorders. New Engl. J. Med., 276, 148-156.

Gaston, L. W., Brooks, J. E., Blumenthal, H. J., and Miller, C. E. (1971). A study of blood coagulation following an acute stroke. Stroke, 2, 81-87.

Geigy AG, Basle (1962). Scientific tables (Documenta Geigy), 6th ed. edited by K. Diem, p. 624. Geigy Pharmaceuticals, Division of Geigy Chemical Corporation. Ardsley, New York.

Goldstein, R. A., Becker, K. L., and Moore, C. F. (1972). Serum urate in healthy men: intermittent elevations and seasonal effect. New Engl. J. Med., 287, 649-650.

Hennecke, A., and Südhoff, H. (1970). Liver involvement in gout. Germ. med. Mth., 15, 395-398.

Juhl, E., Christoffersen, P., Baden, H., and Quaade, F. (1971). Liver morphology and biochemistry in eight obese patients treated with jejunoileal anastomosis. New Engl. J. Med., 285, 543-547.

Leevy, C. M. (1962). Fatty liver: a study of 270 patients with biopsy proven fatty liver and a review of the literature. Medicine (Baltimore), 41, 249-278.

McCullough, F. S., Tzargourinis, M. Greenberger, N. J., and Linscheer, W. G. (1971). Stimulation of insulin secretion by, medium-chain triglycerides in patients with cirrhosis. Gut, 12, 134-138

Mertz, D. P. (1972). Gicht, Diabetes mellitus und Fettlebar. Munch. med. Wschr., 114, 180-185.

Meyerowitz, B. R. (1972). Surgical treatment of intractable morbid obesity (review). Scand. J. Gastroenterol., 7, 1-2.

Noble, R. P. (1968). Electrophoretic separation of plasma proteins in agarose gel. J. Lipid Res., 9, 693-700.

Payne, J. H., and DeWind, L. T. (1969). Surgical treatment of obesity. Amer. J. Surg., 118, 141-147.

Plauchu, M., Pousset, G., Montgolfier, R. de., Guibert, A., and Kressmann, J. (1971). Valeur sémiologique du dosage des triglycérides à jeun dans l'obésité et le diabète. Lyon méd., 225, 201-215.

Rosselin, G. E., Claude, J. R., Eschwege, E. P., Patois, E., Warnet, J. M. and Richard, J. L. (1971). Diabetes survey. Plasma insulin during $\mathbf{0 - 2 h}$ oral glucose tolerance test systematically carried out in a professional group. I. Relationship with plasma glucose, free fatty acids, cholesterol, triglycerides and corpulence. Diabetologia, 7, 34-45.

Salmon, P. A. (1971). The results of small intestinal bypass operations for the treatment of obesity. Surg. Gynec. Obstet., 132, 965-979.

Schaefer, L. E. (1964). Serum cholesterol-triglyceride distribution in a 'normal' New York City population. Amer. J. Med., 36, 262-268.

Schaffner, F., and Popper, H. (1970). Alcoholic hepatitis in the spectrum of ethanol-induced liver injury. Scand. J. Gastroent., Suppl., 7, 69-78.

Shibita, H. R., Mackenzie, J. R., and Huang, S. (1971). Morphologic changes of the liver following small intestine bypass for obesity. Arch. Surg., 103, 229-237.

Smetana, H. F. (1972). Cirrhosis of the liver: principles of classification, histogenesis and pathogenesis. Path. Ann., 7, 107-144.

Stokes, T., and Wynn, V. (1971). Serum-lipids in women on oral contraceptives. Lancet, 2, 677-681.

Wasastjerna, C., Reissell, P., Karjalainen, J., and Ekelund, P. (1972). Fatty liver in diabetes. Acta med. scand., 191, 225-228.

Westwater, J. O., and Fainer, D., (1958). Liver impairment in the obese. Gastroenterology, 34, 686-693.

Zelman, S. (1952). The liver in obesity. Arch. intern. Med., 90, 141-156 